\title{
A szénhidrát-anyagcsere és a gyulladásos folyamatok jellemzésére szolgáló új marker, a szérumprogranulin diagnosztikai és prognosztikai szerepéról
}

\author{
Nádró Bíborka dr. - Sztanek Ferenc dr. - Lörincz Hajnalka dr. \\ Páll Dénes dr. - Paragh György dr. - Harangi Mariann dr. \\ Debreceni Egyetem, Általános Orvostudományi Kar, Anyagcsere Betegségek Tanszék, \\ Belgyógyászati Intézet, Debrecen
}

\begin{abstract}
A progranulin egy újonnan felfedezett multifunkcionális glikoprotein, amely összefüggésben van az elhízás és a cukorbetegség kialakulásával. A progranulin a tumornekrózisfaktor- $\alpha$ endogén antagonistája, kompetitíven kötődik annak receptorához, így antiinflammatoricus aktivitással rendelkezik. Érdekes módon korábbi tanulmányok kimutatták, hogy a progranulin szérumszintje emelkedett a cukorbetegekben, és összefüggésbe hozták a cukorbetegség bizonyos komplikációival, beleértve a micro- és macroangiopathiát, a macroalbuminuriát és a csökkent vesefunkciót. Továbbá a hyperprogranulinaemia közrejátszhat az elhízáshoz társuló inzulinrezisztencia patogenezisében. A cikkben összefoglaljuk a jelenleg elérhetô adatokat a progranulinnak - mint új markernek - a szénhidrát-metabolizmusban és a gyulladásban betöltött szerepére vonatkozóan.
\end{abstract}

Orv Hetil. 2019; 160(25): 973-979.

Kulcsszavak: progranulin, gyulladás, diabetes mellitus, microangiopathia

Diagnostic and prognostic roles of serum progranulin, a novel marker of the carbohydrate metabolism and inflammation

Progranulin is a recently recognized multifunctional glycopeptide shown to be related to obesity and diabetes mellitus. Progranulin is an endogenous antagonist of tumor necrosis factor- $\alpha$ by competitively binding to its receptor, therefore, it exerts anti-inflammatory activity. Paradoxically, previous studies have shown that serum levels of progranulin were elevated in patients with diabetes and associated to its complications including micro- and macroangiopathies, macroalbuminuria or reduced renal function. Moreover, hyperprogranulinemia may be involved in the pathogenesis of obesity-associated insulin resistance. The review summarizes the currently available data on progranulin as a novel marker of the carbohydrate metabolism and inflammation.

Keywords: progranulin, inflammation, diabetes mellitus, microangiopathy

Nádró B, Sztanek F, Lőrincz H, Páll D, Paragh Gy, Harangi M. [Diagnostic and prognostic roles of serum progranulin, a novel marker of the carbohydrate metabolism and inflammation]. Orv Hetil. 2019; 160(25): 973-979.

(Beérkezett: 2018. november 9.; elfogadva: 2018. november 29.) 


\section{Rövidítések}

$\mathrm{BMI}=($ body mass index $)$ testtömegindex $; \mathrm{CpG}=($ cytosine phosphate-guanine) citozin-foszfát-guanin; ERK = (extracellular signal-regulated kinase) extracellulárisan szabályozott kináz; grn = granulin $; \mathrm{HDL}=($ high-density lipoprotein $)$ magas sürüségú lipoprotein; IFG = (impaired fasting glucose $)$ emelkedett éhomi vércukor; IGT = (impaired glucose tolerance) csökkent cukortolerancia; IRS = inzulinreceptor-szubsztrát; $\mathrm{kDa}=$ kilodalton; $\mathrm{LDL}=($ low-density lipoprotein $)$ alacsony sürüségű lipoprotein; mRNS = (messenger) hírvivő RNS; PI3K = foszfatidilinozitol-3-kináz; pgrn = progranulin; RNS = ribonukleinsav; SLPI $=$ (secretory leukocyte protease inhibitor) szekretoros leukocyta proteáz inhibitor; $\mathrm{TNF} \alpha=$ (tumor necrosis factor alpha) tumornekrózisfaktor-alfa

A 2-es típusú diabetes mellitus napjainkban világszerte népbetegségnek számít; jelenlegi globális becsült prevalenciája 8,8\%, azaz minden 11 emberból egyet érint $[1,2]$. Az egyre növekvő átlagéletkor, a túlsúly és elhízás gyakoribbá válása miatt a prevalencia várhatóan tovább nő az elkövetkezendő években. A diabetes jelentősen növeli a macroangiopathia, azaz a szív- és érrendszeri betegségek [3] és egyes microangiopathiás szövődmények, köztük a retinopathia, a neuropathia és a nephropathia kialakulásának kockázatát $[4,5]$, melyek alapvetően meghatározzák a betegek életminőségét és életkilátásait. Ismert, hogy a krónikus gyulladásos folyamatok elősegítik a diabetes és ezzel párhuzamosan az érelmeszesedés, valamint egyéb szövődmények kialakulását [6]. Ugyanakkor a mindennapi gyakorlatban nehéz olyan markert találni, mely előre jelezheti a diabeteses betegek cardiovascularis kockázatát és a szövődmények kialakulásának valószínúségét. A tradicionális diabetesbiomarkerek mellett intenzíven kutatják újabb, főként a gyulladásos folyamatokat szabályozó markerek lehetséges alkalmazását [7-9]. Az utóbbi években néhány új fehérje potenciális szerepe merült fel, ezek közé tartozik a progranulin.

\section{A progranulin mint növekedési faktor}

A progranulin egy erôsen glikolizált, $68,5 \mathrm{kDa}$ molekulasúlyú növekedési faktor [10-14], amelyet epithelinprekurzornak [11], acrograninnak [13] vagy PC-sejt-eredetű növekedési faktornak [12] is neveznek. A progranulint számos kutatócsoport egymástól függetlenül fedezte fel, ez magyarázza a szinonimák megjelenését. A növekedési faktorok és a hozzájuk kapcsolódó jelátviteli útvonalak számos biológiai folyamatban vesznek részt, szabályozzák a fejlődést, az egészséges szövetek fenntartását és javítását. Ezeken kívül kóros folyamatok résztvevői is lehetnek, mint például tumorkialakulás és -progresszió. A progranulin az extracellulárisan szabályozott kináz (ERK) és foszfatidilinozitol-3-kináz (PI3K) útvonalon keresztül részt vesz a szöveti gyógyulás, valamint a tumorképződés folyamatának szabályozásában [15]. A progranulin jelentősége felmerült különböző malignus betegségek kialakulásában, köztük az emlő- [16], a pete- fészek- [17], különböző emésztôszervi [18] és vesedaganatok [19] esetén.

A progranulin a szerkezetét tekintve 7,5 ismétlódő egységből épül fel, melyben egy egység 12 ciszteingranulin-doménbő́l áll [20]. A granulin/epithelin egység 4, egymás feletti $\beta$-redőből áll, melyek tekeredő, létraszerü formációt alkotnak, melyben diszulfidhidak alkotnak egy központi tengelyt (1. ábra) [2l]. Ez a szerkezeti motívum más fehérjékben nem fordul elő, kivéve bizonyos növényi tiol-proteázokat $[20,22]$.

A humán genomban egy progranulin gént azonosítottak, GRN (PGRN-gén), mely a 17-es kromoszóma hosszú karján a 21.32-es lókuszon helyezkedik el, míg egérben a 11 -es kromoszómán található (grn), és 12 exont tartalmaz $[23,24]$.

A progranulingén jelen ismereteink szerint nem kapcsolható egyértelmúen egyetlen genetikai betegséghez sem.

A progranulingén a szervezet szinte összes szövetében expresszálódik. In vivo a progranulin 'messenger' ribonukleinsav (mRNS) a gyors anyagcseréjü sejtekben prominensen fordul elő, főleg a bélhámsejtek kriptáiban és az epidermalis keratinocytákban. A progranulin felnőttekben az egészséges endotheliumban nem expresszálódik, de granulációs szövetben a kapillárisendothelium aktiválódik, és serkenti a mitózist és a dermalis microvascularis sejtek migrációját. A mitotikusan kevésbé aktív sejtekben (például alveolusok, renalis tubulussejtek) a progranulingén kisebb mértékben expresszálódik. Ezek alapján arra lehet következtetni, hogy a progranulinnak az epithelialis proliferatio szabályozásában van kiemelt szerepe $[13,25,26]$.

A sebgyógyulás nagyon jó élettani példa a fiziológiás növekedésifaktor-aktivációra. Ha egy szúrást ejtünk a bőrön, akkor a szúrás után nem sokkal a progranulinmRNS-szint a bőrsérülésben megnő, és legalább 10 napig emelkedett marad [21]. Számos különböző forrása van a progranulinnak a sérült bőrben, például a keratinocyták, melyek a sérült és az egészséges bőrben is expreszszálják a progranulin-mRNS-t [21]. A gyulladásos sejtek nagy mennyiségben termelik a proganulint, mihelyt a sebbe lépnek. A dermalis fibroblastok és endothelsejtek ép állapotban nem expresszálnak progranulin-mRNS-t, azonban sérülés hatására gyors és jelentős mértékű génexpresszió indukálódik (2. ábra) [21].

Azt figyelték meg, hogy ha patkányok bőrsebébe progranulint adnak, akkor a gyulladásos sejtek infiltrációja, főképp a neutrophil granulocyták száma növekszik, és a fibroblastok száma és az erek újdonképződése is nő a sebben, azonban az extracelluláris mátrix mennyisége nem gyarapodott. Ezek az eredmények azt támasztják alá, hogy a progranulinnak a sebgyógyulás granulációs fázisában van szerepe, míg a későbbi, mátrixlerakódási és -összehúzódási szakban kevésbé.

A progranulin szintje a humán plazmában az eddigi vizsgálatok alapján körülbelül $200 \mathrm{ng} / \mathrm{ml}$ [27]; rágcsálók esetén a plazmaszint magasabb, nagyjából $550 \mathrm{ng} / \mathrm{ml}$ 


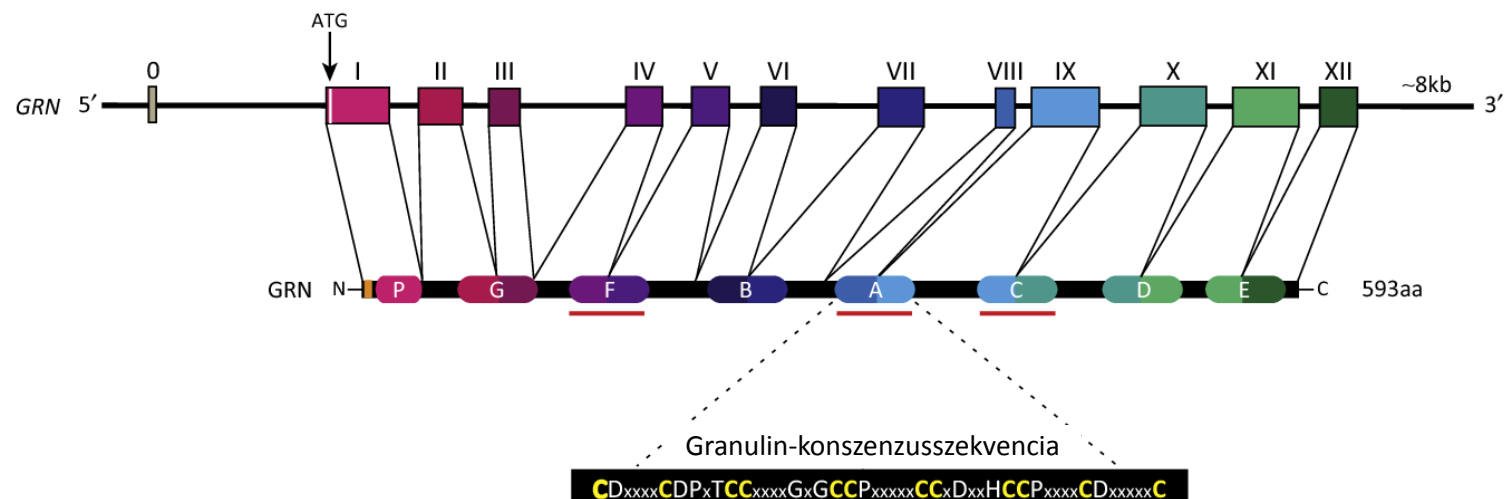

CDxxxx CDPxTCC $x x x x$ GxGCCP $x_{x x x x} C_{x} D_{x x} H C C P_{x x x x} C D_{x x x x x} C$

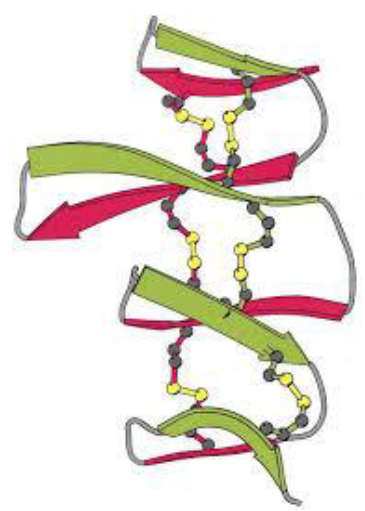

1. ábra

A progranulingén szerkezete és a fehérjeterméke (He és mtsai nyomán) [21]. A római számok az exonokat jelzik, melyek N, C vagy C-N betűvel vannak jelölve attól függően, hogy a domének C- vagy $\mathrm{N}$-terminusát vagy mindkettőt kódolják. A háromdimenziós szerkezeti ábrán a $\beta$-redők és a ciszteinhidak is láthatók

a) Fiziológiás stimulus

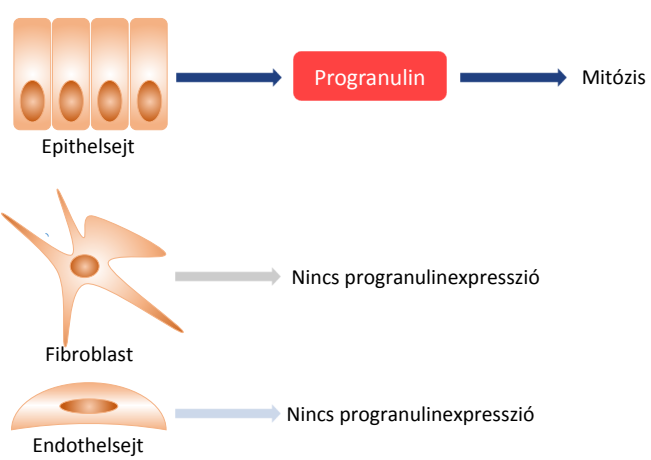

b) Sérülés

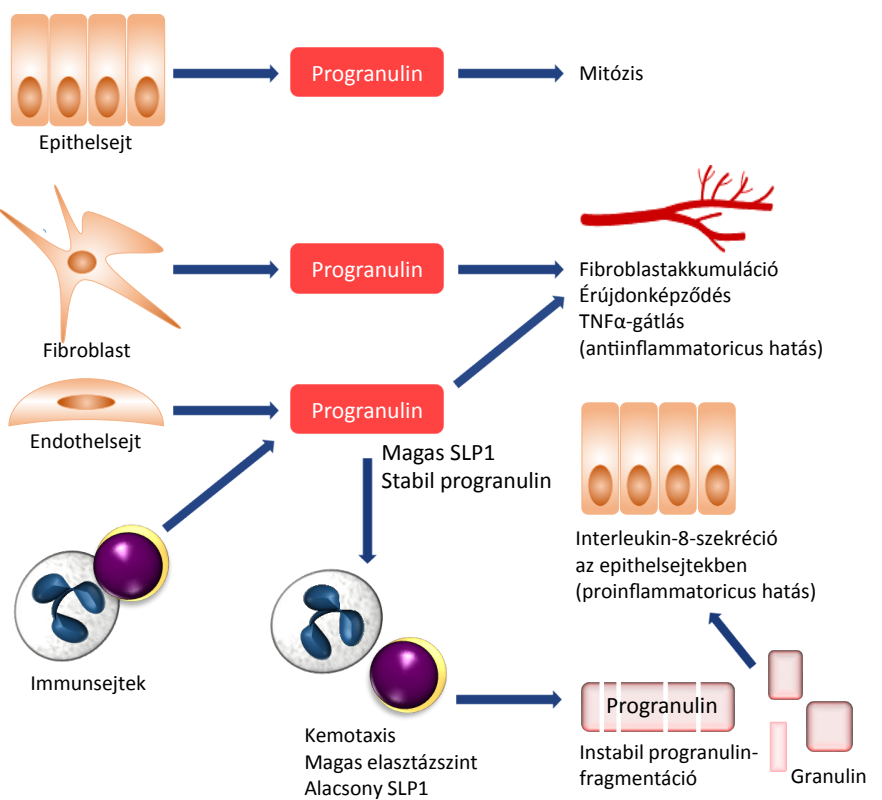

A progranulinaktiválódás modellje bőrsérülés esetén (He és mtsai nyomán) [21]. A progranulin expressziós mintáját és a lehetséges biológiai válaszfolyamatokat ábrázoltuk az (a) és (b) ábrán. Intakt bőr esetén a progranulin az epithelsejtekben termelődik (a), míg sérülés esetén a dermalis fibroblastok és endothelsejtek is termelnek progranulint, aminek hatására fehérvérsejtek lépnek be a szövetbe, melyek önmaguk is képesek progranulintermelésre (b). Sérülés esetén ha a SLPI proteáz inhibitor dominál, akkor a progranulin stabil. Ha az elasztázok és proteázok dominálnak, akkor a progranulin fragmentálódik, és proinflammatoricus válaszok kerülnek előtérbe

SLPI = szekretoros leukocyta proteáz inhibitor-1 
[28]. A progranulin C-terminálisan elhelyezkedő három aminosava képes a szortilinhez kötődni, mely egy multiligand receptorfehérje. A szortilin az intracelluláris fehérjeforgalom szabályozásáért felel a Golgi-rendszerben, és a sejtfelszínen clearance-receptorként múködik. Mindezek alapján a szortilin valószínúleg részt vesz a progranulin degradációjában, befolyásolva ezzel a keringő progranulin szintjét [29].

\section{A progranulin szerepe a gyulladásos folyamatokban}

A humán és az egér-progranulingén promóter régiója is tartalmaz potenciális gyulladásmediált promóter elemeket, melyek indirekten annak szerepét jelzik a gyulladásos folyamatokban. Az intakt progranulint a proteázok (neutrophil elasztázok, proteáz-3, mátrixmetalloproteázok stb.) kisebb, kb. 6 kDa nagyságú fehérjékre, ún. granulinokra hasítják, melyek szintén részt vesznek a sejtek múködésének és növekedésének szabályozásában. Míg az intakt, teljes hosszúságú progranulin döntően antiinflammatoricus hatást fejt ki, addig a granulinok fokozzák a gyulladásos citokinek, köztük az interleukin-8 expreszszióját [10].

A szekretoros leukocyta proteáz inhibitor (SLPI) sebekben betöltött szerepének kutatása közben merült fel a progranulin közremúködése a gyulladásos kaszkádban. A SLPI a neutrophil elasztáz és a pancreaticus kimotripszin proteáz enzimek inhibitora. Gátolja a makrofágok és monocyták gyulladásos válaszát a különböző mikrobiális termékekre. A SLPI-gén törlése egerekben súlyos sebgyógyulási zavart okoz [30]. Az elasztázok hasítják a progranulint a grn/epi domének között, ezáltal granulinok képződnek; a SLPI azonban gátolja a proteázokat. A gyulladásos mikrokörnyezetben tehát az intakt progranulin és a granulinok aránya a SLPI szintjétől függ (2. ábra).

Először 2011-ben írták le, hogy a progranulin kompetitíven gátolja a tumornekrózisfaktor-alfa $(\mathrm{TNF} \alpha)$ receptorát, blokkolva ezzel a TNF $\alpha$ által közvetített jelátviteli útvonalakat, ami megmagyarázza a progranulin antiinflammatoricus hatásainak egy részét [31]. A proganulin gátolja a neutrophil granulocyták TNF $\alpha$ által mediált terjedését és degranulációját, de a kitapadást nem. Természetesen lehetséges, hogy a progranulin egyéb tumornekrózisfaktor-receptorokhoz vagy más receptorfehérjékhez is kötődni képes.

A granulinok (grnA/epil és grnB/epi2) ezzel szemben nem képesek kötődni a TNF $\alpha$-receptorhoz, így nem befolyásolják a TNF $\alpha$ által indukált válaszokat. Képesek fokozni a neutrophil kemotaktikus faktor interleukin-8 szekrécióját epithelialis sejtvonalakból, míg a progranulin nem. A granulinok receptorairól keveset tudunk. A granulinok az ún. CpG oligonukleotidok kofaktoraiként múködnek - ezek gyakoriak a bakteriális DNS-ben -, melyek segítségével azok a toll-like receptor-9-hez kö- tődnek, így szerepük felmerül a természetes immunválasz kialakulásában [32].

Tehát a SLPI megvédi a progranulint a proteolízistől a gyulladásos környezetben, azonban nem kötődik a grn/ epi fragmentekhez, és nem képes gátolni azok proinflammatoricus hatásait. Ugyanakkor vannak adatok arra, hogy a progranulin képes homodimert képezni a keringésben, mely befolyásolhatja a SLPI-hez történő kötődését és ezáltal a proteolízisre való hajlamát [33].

Minden olyan kórképben, melyben a gyulladásos folyamatok kulcsszerepet játszanak az adott betegség kialakulása s progressziója szempontjából, a progranulin szerepének vizsgálata indokolt lehet. A progranulin antiinflammatoricus hatását igazolták a psoriasisban [34], rheumatoid arthritisben [35] és ischaemiás-reperfúziós károsodásban [36] elvégzett korábbi vizsgálatok, míg a diabetes, metabolikus szindróma, elhízás és inzulinrezisztencia esetén a progranulint mint proinflammatoricus tényezôt azonosították [37]. Az alábbiakban a progranulin cukorbetegségben betöltött szerepét foglaljuk össze.

\section{A progranulin cukorbetegségben betöltött szerepéről}

A 2-es típusú diabetes mellitus patogenezisében döntő szerepet játszik a zsírszövet felszaporodása és az inzulinrezisztencia megjelenése, ami hyperglykaemia kialakulásához vezet [38]. A progranulin szerepét diabetes mellitusban számos korábbi munkacsoport vizsgálta, melyek a progranulin kóroki szerepét támasztják alá. A progranulin szintje pozitívan korrelál a testzsírszázalékkal és a haskörfogattal. Emellett a progranulin fokozza a zsírszövetben a gyulladásos sejtek kemotaxisát és citokintermelését, köztük az interleukin-6 expresszióját, elősegítve ezzel a zsírszöveti krónikus alacsony fokú gyulladás kialakulását [39]. A progranulin befolyásolhatja az inzulinszignalizációt, és blokkolhatja az inzulinstimulált glükózfelvételt a zsírsejtekbe [31] (3. ábra) [37]. Adipocyta-sejtvonalon a külsőleg hozzáadott progranulin dózisfüggő módon gátolta az inzulinreceptorszubsztrát (IRS)-1 foszforilációját, ezáltal blokkolta az inzulinmediált jelátviteli folyamatokat. Ugyanakkor az inzulinreceptor-foszforilációt nem befolyásolta [40].

Leírták, hogy a szérumprogranulin-szint 2-es típusú diabeteses betegekben szignifikánsan, körülbelül 1,4-szer magasabb, mint az egészséges populációban [27]. A gyulladás fontos szerepet játszik a metabolikus szindróma és az atherosclerosis patofiziológiájában is. A progranulin egyfajta modulátorként viselkedik a különböző gyulladásos folyamatokban azáltal, hogy speciális hatással van a célszövetekre [27]. A magasabb szérumprogranulin-szint inkább a csökkent glükóztoleranciával (impaired glucose tolerance - IGT) asszociálódik, mint a magas éhomi glükózszinttel (impaired fasting glucose - IFG) [39]. Egereken végzett tanulmányban bizonyították, hogy a progranulin inzulinrezisztenciát indukált [41]. 


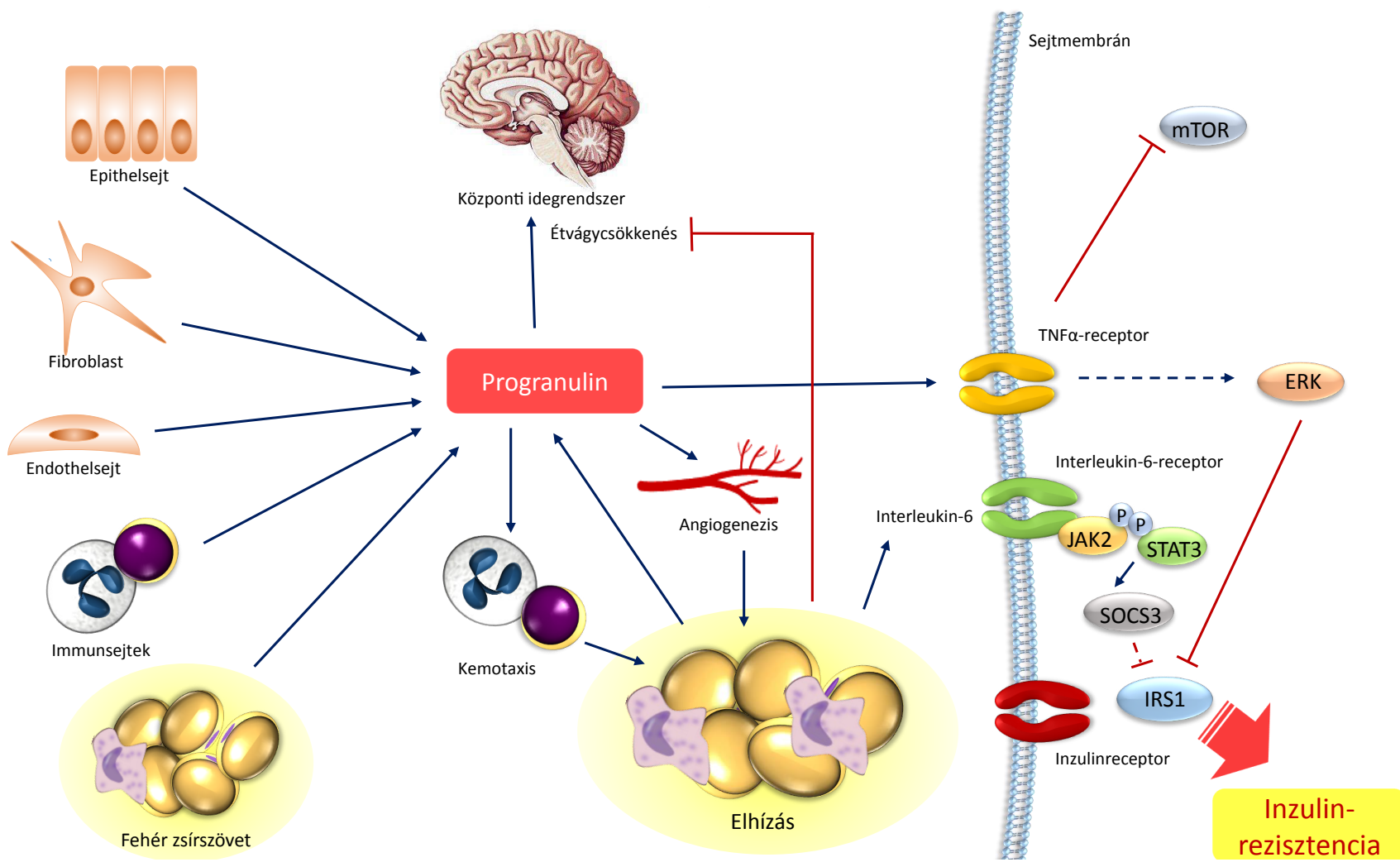

3. ábra

A progranulin lehetséges szerepe az inzulinrezisztencia kialakulásában (Nicoletto és Camani nyomán) [37]. A progranulin fokozza a zsírszövetben a gyulladásos sejtek kemotaxisát és citokintermelését, köztük az interleukin-6 expresszióját, elősegítve ezzel a zsírszöveti krónikus alacsony fokú gyulladás kialakulását. A progranulin gátolja az inzulinreceptor-szubsztrát (IRS)-l foszforilációját, ezáltal blokkolja az inzulinmediált jelátviteli folyamatokat, elősegítve az inzulinrezisztencia kialakulását

Az irodalomban megtalálhatók humán populáción végzett mérések eredményei is. Egyes kutatócsoportok nem találtak szignifikáns összefüggést a progranulinszint és a metabolikus szindróma egyetlen komponense között sem [42], mások szignifikáns összefüggést találtak a progranulinszint és a haskörfogat, a diasztolés vérnyomás, a magasabb éhgyomri glükóz, egyes lipidparaméterek [42], a BMI, a teljes testzsírtömeg, a zsigeri zsírmennyiség és az összkoleszterinszint [27] között. Más kutatócsoportok szerint a plazmaprogranulin-szint pozitívan korrelál az éhgyomri glükózszinttel, a haskörfogattal, az LDL-koleszterin- és trigliceridszintekkel, és negatívan a HDL-koleszterin-szinttel [33]. Több tanulmány is leírta, hogy szignifikánsan emelkedett szérumprogranulin-szint alakul ki 2-es típusú diabeteses és metabolikus szindrómás betegekben [27, 43, 44].

Speciális, szövődményekkel rendelkező diabeteses betegcsoportokon is vizsgálták a progranulin szerepét, és azt találták, hogy a progranulin valószínúleg szerepet játszik a diabeteses microangiopathia patogenezisében. Eredményeik alapján a macroalbuminuriás, proliferatív retinopathiás betegekben a progranulin szintje szignifikánsan emelkedett a normálpopulációhoz és a szövődmény nélküli cukorbetegekhez képest is [45]. Ezek alapján megállapították, hogy a progranulin a krónikus gyulladásos válasz biomarkerének tekinthető diabeteses microangiopathiában.

\section{Következtetések}

Mindezek alapján a progranulin hatása fiziológiás körülmények között kedvező, antiinflammatoricus, míg patológiás körülmények között, például cukorbetegség esetén kedvezőtlen lehet, elősegítve a micro- és macroangiopathiás szövődmények kialakulását. A progranulinszint vizsgálata ezért hasznos lehet a cukorbetegséget kísérő szövődmények prognosztikai markereként, de új terápiás célpontot is jelenthet a diabeteses szövődmények megelőzésében. A cukorbetegek növekvő száma, a szövődmények okozta gyakori hospitalizáció és megnövekedett kezelési költségek miatt a szövődmények kialakulására való hajlam korai felismerése elősegítheti az időben történő közbelépést, a szövődmények megelőzését, azok időbeli kezelését, ezáltal javítva a betegek életminőségét és túlélési esélyeit. Fontos hangsúlyozni ugyanakkor, hogy nem minden esetben tisztázott, hogy a progranulinszint emelkedése oka vagy következménye az egyes kórképekben megfigyelt részfolyamatoknak, így további vizsgálatok szükségesek a progranulin szerepének pontosabb megismeréséhez az egyes krónikus gyulladásos kórképek, így a 2-es típusú diabetes esetén.

Anyagi támogatás: A publikáció elkészítését a GINOP-2.3.2-15-2016-00062. számú projekt támogat- 
ta. A projekt az Európai Unió támogatásával, az Európai Regionális Fejlesztési Alap társfinanszírozásával valósult meg.

Szerzői munkamegosztás: N. B., L. H. a kézirat szerkesztésében, N. B., Sz. F. a szakirodalmi adatok feldolgozásában, H. M. az ábrák elkészítésében és a kézirat összeállításában, P. D., P. Gy. a végső változat ellenőrzésében múködött közre. A cikk végleges változatát valamennyi szerző elolvasta és jóváhagyta.

Érdekeltségek: A szerzóknek nincsenek érdekeltségeik.

\section{Irodalom}

[1] Weisman A, Fazli GS, Johns A, et al. Evolving trends in the epidemiology, risk factors, and prevention of type 2 diabetes: a review. Can J Cardiol. 2018; 34: 552-564.

[2] Zheng Y, Ley SH, Hu FB. Global aetiology and epidemiology of type 2 diabetes mellitus and its complications. Nat Rev Endocrinol. 2018; 14: 88-98.

[3] Kalofoutis C, Piperi C, Kalofoutis A, et al. Type II diabetes mellitus and cardiovascular risk factors: current therapeutic approaches. Exp Clin Cardiol. 2007; 12: 17-28.

[4] Veldman BA, Vervoort G. Pathogenesis of renal microvascular complications in diabetes mellitus. Neth J Med. 2002; 60: 390396.

[5] Khalil H. Diabetes microvascular complications - a clinical update. Diabetes Metab Syndr. 2017; 11(Suppl 1): S133-S139.

[6] Nunemaker CS. Considerations for defining cytokine dose, duration, and milieu that are appropriate for modeling chronic lowgrade inflammation in type 2 diabetes. J Diabetes Res. 2016; 2016: 2846570.

[7] Dorcely B, Katz K, Jagannathan R, et al. Novel biomarkers for prediabetes, diabetes, and associated complications. Diabetes Metab Syndr Obes. 2017; 10: 345-361.

[8] Márk L, Harangi M, Paragh G. The labyrinth of residual risk: reduction of the remaining lipid and inflammation risk in the prevention of atherosclerosis. [A residualis kockázat útvesztôi: a maradék lipid és gyulladásos kockázat csökkentése az atherosclerosis prevenciójában.] Orv Hetil. 2018; 159: 124-130. [Hungarian]

[9] Babik B, Peták F, Agócs S, et al. Diabetes mellitus: endothelial dysfunction and changes in hemostasis. [Diabetes mellitus: endotheldiszfunkció és haemostasiselváltozások.] Orv Hetil. 2018; 159: 1335-1345. [Hungarian]

[10] Bateman A, Bennett HP. Granulins: the structure and function of an emerging family of growth factors. J Endocrinol. 1998; 158: $145-151$

[11] Plowman GD, Green JM, Neubauer MG, et al. The epithelin precursor encodes two proteins with opposing activities on epithelial cell growth. J Biol Chem. 1992; 267: 13073-13078.

[12] Zhou J, Gao G, Crabb JW, et al. Purification of an autocrine growth factor homologous with mouse epithelin precursor from a highly tumorigenic cell line. J Biol Chem. 1993; 268: 1086310869.

[13] Baba T, Hoff HB 3rd, Nemoto H, et al. Acrogranin, an acrosomal cysteine-rich glycoprotein, is the precursor of the growthmodulating peptides, granulins, and epithelins, and is expressed in somatic as well as male germ cells. Mol Reprod Dev. 1993; 34: 233-243.

[14] Bhandari V, Palfree RG, Bateman A. Isolation and sequence of the granulin precursor cDNA from human bone marrow reveals tandem cysteine-rich granulin domains. Proc Natl Acad Sci U S A 1992; 89: 1715-1719.
[15] He Z, Bateman A. Progranulin gene expression regulates epithe lial cell growth and promotes tumor growth in vivo. Cancer Res. 1999; 59: 3222-3229.

[16] Koo DH, Park CY, Lee ES, et al. Progranulin as a prognostic biomarker for breast cancer recurrence in patients who had hormone receptor-positive tumors: a cohort study. PLoS ONE 2012; 7: e39880.

[17] Han JJ, Yu M, Houston N, et al. Progranulin is a potential prognostic biomarker in advanced epithelial ovarian cancers. Gynecol Oncol. 2011; 120: 5-10.

[18] Demorrow S. Progranulin: a novel regulator of gastrointestinal cancer progression. Transl Gastrointest Cancer 2013; 2: 145151.

[19] Donald CD, Laddu A, Chandham P, et al. Expression of progranulin and the epithelin/granulin precursor acrogranin correlates with neoplastic state in renal epithelium. Anticancer Res. 2001; 21: 3739-3742.

[20] Hrabal R, Chen Z, James S, et al. The hairpin stack fold, a novel protein architecture for a new family of protein growth factors. Nat Struct Biol. 1996; 3: 747-752.

[21] He Z, Ong CH, Halper J, et al. Progranulin is a mediator of the wound response. Nat Med. 2003; 9: 225-229.

[22] Tolkatchev D, Ng A, Vranken W, et al. Design and solution structure of a well-folded stack of two $\beta$-hairpins based on the amino-terminal fragment of human granulin A. Biochemistry 2000; 39: 2878-2886.

[23] Bhandari V, Bateman A. Structure and chromosomal location of the human granulin gene. Biochem Biophys Res Commun. 1992; 188: 57-63.

[24] Bucan M, Gatalica B, Baba T, et al. Mapping of GRN, the gene encoding the granulin/epithelin precursor (acrogranin), to mouse Chromosome 11. Mamm Genome 1996; 7: 704-705.

[25] Bhandari V, Giaid A, Bateman A. The complementary deoxyribonucleic acid sequence, tissue distribution, and cellular localization of the rat granulin precursor. Endocrinology 1993; 133: 2682-2689.

[26] Daniel R, He Z, Carmichael KP, et al. Cellular localization of gene expression for progranulin. J Histochem Cytochem. 2000; 48: 999-1009.

[27] Finch N, Baker M, Crook R, et al. Plasma progranulin levels predict progranulin mutation status in frontotemporal dementia patients and asymptomatic family members. Brain 2009; 132(Pt 3): 583-591.

[28] Martens LH, Zhang J, Barmada SJ, et al. Progranulin deficiency promotes neuroinflammation and neuron loss following toxininduced injury. J Clin Invest. 2012; 122: 3955-3959.

[29] Zheng Y, Brady OA, Meng PS, et al. C-terminus of progranulin interacts with the beta-propeller region of sortilin to regulate progranulin trafficking. PLoS ONE 2011; 6: e21023.

[30] Zhu J, Nathan C, Jin W, et al. Conversion of proepithelin to epithelins: roles of SLPI and elastase in host defense and wound repair. Cell 2002; 111: 867-878.

[31] Tang W, Lu Y, Tian QY, et al. The growth factor progranulin binds to TNF receptors and is therapeutic against inflammatory arthritis in mice. Science 2011; 332: 478-484.

[32] Park B, Buti L, Lee S, et al. Granulin is a soluble cofactor for tolllike receptor 9 signaling. Immunity $2011 ; 34: 505-513$.

[33] Nguyen AD, Nguyen TA, Cenik B, et al. Secreted progranulin is a homodimer and is not a component of high density lipoproteins (HDL). J Biol Chem. 2013; 288: 8627-8635.

[34] Huang K, Chen A, Zhang X, et al. Progranulin is preferentially expressed in patients with psoriasis vulgaris and protects mice from psoriasis-like skin inflammation. Immunology 2015; 145: 279-287.

[35] Yamamoto Y, Takemura M, Serrero G, et al. Increased serum GP88 (progranulin) concentrations in rheumatoid arthritis. Inflammation 2014; 37: 1806-1813. 
[36] Zhou M, Tang W, Fu Y, et al. Progranulin protects against renal ischemia/reperfusion injury in mice. Kidney Int. 2015; 87: 918929.

[37] Nicoletto BB, Canani LH. The role of progranulin in diabetes and kidney disease. Diabetol Metab Syndr. 2015; 7: 117.

[38] Langenberg C, Sharp SJ, Schulze MB, et al. Long-term risk of incident type 2 diabetes and measures of overall and regional obesity: the EPIC-InterAct case-cohort study. PLoS Med. 2012; 9: el001230

[39] Youn BS, Bang SI, Klöting N, et al. Serum progranulin concentrations may be associated with macrophage infiltration into omental adipose tissue. Diabetes 2009; 58: 627-636.

[40] Matsubara T, Mita A, Minami K, et al. PGRN is a key adipokine mediating high fat diet-induced insulin resistance and obesity through IL-6 in adipose tissue. Cell Metab. 2012; 15: 38-50.

[41] Carecchio M, Fenoglio C, De Riz M, et al. Progranulin plasma levels as potential biomarker for the identification of GRN deletion carriers. A case with atypical onset as clinical amnestic mild cognitive impairment converted to Alzheimer's disease. J Neurol Sci. 2009; 287: 291-293.
[42] Shafaei A, Marjani A, Khoshnia M. Serum progranulin levels in type 2 diabetic patients with metabolic syndrome. Rom J Intern Med. 2016; 54: 211-216

[43] Faerch K, Vaag A, Witte DR, et al. Predictors of future fasting and 2-h post-OGTT plasma glucose levels in middle-aged men and women - the Inter99 study. Diabet Med. 2009; 26: 377383.

[44] Qu H, Deng H, Hu Z. Plasma progranulin concentrations are increased in patients with type 2 diabetes and obesity and correlated with insulin resistance. Mediators Inflamm. 2013; 2013: 360190.

[45] Xu L, Zhou B, Li H, et al. Serum levels of progranulin are close ly associated with microvascular complication in type 2 diabetes. Dis Markers 2015; 2015: 357279.

(Harangi Mariann dr., Debrecen, Nagyerdei krt. 98., 4032 e-mail: harangi@belklinika.com)

\title{
XIX. Romhányi Orvostalálkozó - Lelkigyakorlat (manréza) orvosoknak Szár, 2019. augusztus 31. Moderátor: Prof. Dr. Szelényi Zoltán
}

\author{
Délelötti program \\ goo Szentmise \\ $10^{00}$ Üdvözlések \\ Németh Norbert (polgármester) \\ Prof. Dr. Kellermayer Miklós: „Gyógyszer az örökhalál ellen” \\ $10^{30}$ Márfi Gyula (veszprémi érsek): A betegség hordozása és gyógyítása - mint szakrális cselekedet \\ $11^{00}$ Legeza József (teológus, görög katolikus parókus): A magyar görögkatolikus egyház története, helyzete \\ $11^{30}$ Rieger Tibor (szobrászművész): A müvészet szellemi alapjai a Koronázó palásttól napjainkig \\ Romhányi-emléktábla megkoszorúzása
}

\section{Délutáni program}

$14^{00}$ Prof. Dr. Poór Gyula: A kórház legyen több, mint kórház

$14^{30}$ Prof. Dr. Losonczy Hajna: Az immunglobulin profilaxis jelentősége krónikus lymphoid leukémiában

$15^{00}$ Prof. Dr. Emődy Levente: Romhányi György klinikopatológiai szemléletének példája az utódgenerációk számára

$15^{30}$ Prof. Dr. Kondákor István: A hívő orvos

Genzwein Ferenc sírjának megkoszorúzása

A cikk a Creative Commons Attribution 4.0 International License (https://creativecommons.org/licenses/by/4.0/) feltételei szerint publikált Open Access közlemény, melynek szellemében a cikk bármilyen médiumban szabadon felhasználható, megosztható és újraközölhetö, feltéve, hogy az eredeti szerzỏ és a közlés helye, illetve a CC License linkje és az esetlegesen végrehajtott módosítások feltüntetésre kerülnek. (SID_1) 